\title{
Nitrous oxide produces minimal hemodynamic changes in patients receiving a propofol-based anesthetic: an esophageal Doppler ultrasound study
}

\author{
[Le protoxyde d'azote produit des changements hémodynamiques minimes chez des patients qui
}

reçoivent une anesthésie à base de propofol : une étude de l'effet Doppler asophagien]

Toshiya Shiga MD PhD, ${ }^{*}$ Zen'ichiro Wajima MD PhD, ${ }^{*}$ Tetsuo Inoue MD PhD, ${ }^{*}$ Ryo Ogawa MD PhD $\dagger$

\begin{abstract}
Purpose: Nitrous oxide $\left(\mathrm{N}_{2} \mathrm{O}\right)$ is a frequently used adjunct to propofol anesthesia. Although $\mathrm{N}_{2} \mathrm{O}$ reduces the requirement of propofol for induction and maintenance, the effects of both drugs on overall hemodynamics remain controversial. We tested the hypothesis that the addition of $\mathrm{N}_{2} \mathrm{O}$ to therapeutic doses of propofol alters hemodynamics and Doppler-derived variables evaluated with the esophageal Doppler monitor in a randomized, doubleblinded, placebo-controlled design.
\end{abstract}

Methods: Thirty ASA I-II patients (aged 30-66 yr) were randomly assigned to receive propofol with oxygen-enriched air $\left(\mathrm{FlO}_{2}=\right.$ 0.3 ; air group) or propofol with $70 \% \mathrm{~N}_{2} \mathrm{O}\left(\mathrm{N}_{2} \mathrm{O}\right.$ group). Following intubation, a computerized target-controlled infusion technique was used to administer propofol from $0 \mu \mathrm{g} \cdot \mathrm{mL}^{-1}$ (baseline) to 5 $\mu \mathrm{g} \cdot \mathrm{mL}^{-1}$ in I $\mu \mathrm{g} \cdot \mathrm{mL}^{-1}$ increments.

Results: Mean arterial pressure (MAP) decreased more in the $\mathrm{N}_{2} \mathrm{O}$ group than in the air group only at $5 \mu \mathrm{g} \cdot \mathrm{mL}^{-1}$. Aortic blood flow (ABF) showed a similar dose-dependent decrease in both groups. Peak aortic flow acceleration, as a myocardial contractility index, decreased significantly and similarly in both groups in a dosedependent manner whereas peak velocity of $\mathrm{ABF}$, as another measure of myocardial contractility, remained unchanged. Heart rate-corrected left ventricular ejection time, as a measure of preload, remained constant in both groups at any target plasma concentration.

Conclusion: Propofol causes dose-dependent decreases in ABF and MAP; however, $70 \% \mathrm{~N}_{2} \mathrm{O}$ produces minimal hemodynamic and Doppler-derived variable changes under target-controlled propofol infusion at therapeutic concentrations.
Objectif: Le protoxyde d'azote $\left(\mathrm{N}_{2} \mathrm{O}\right)$ complète souvent l'anesthésie au propofol. Quoique le $\mathrm{N}_{2} \mathrm{O}$ réduise la quantité de propofol nécessaire à l'induction et au maintien de l'anesthésie, les effets des deux médicaments sur l'hémodynamique générale demeurent controversés. Nous avons testé l'hypothèse voulant que l'ajout de $\mathrm{N}_{2} \mathrm{O}$ à des doses thérapeutiques de propofol modifie l'hémodynamique et les variables dérivées de l'examen Doppler évaluées avec un moniteur Doppler œesophagien dans une étude randomisée, à double insu et contrôlée par placebo.

Méthode : Trente patients d'état physique ASA I-II (de 30 à 66 ans), répartis de façon aléatoire, ont reçu du propofol avec de l'air enrichi d'oxygène $\left(\mathrm{FIO}_{2}=0,3\right.$; groupe air) ou du propofol avec $70 \%$ de $\mathrm{N}_{2} \mathrm{O}$ (groupe $\mathrm{N}_{2} \mathrm{O}$ ). Après l'intubation, une technique informatisée de perfusion cible contrôlée a été utilisée pour administrer du propofol de $0 \mu \mathrm{g} \cdot \mathrm{mL}^{-1}$ (mesure de base) à $5 \mu \mathrm{g} \cdot \mathrm{mL}^{-1}$ en paliers de I $\mu \mathrm{g} \cdot \mathrm{mL}^{-1}$.

Résultats : La tension artérielle moyenne (TAM) a baissé davantage avec le $\mathrm{N}_{2} \mathrm{O}$ qu'avec l'air, seulement à $5 \mu \mathrm{g} \cdot \mathrm{mL}^{-1}$. Le débit sanguin aortique (DSA) a montré une baisse dose-dépendante similaire dans les deux groupes. L'accélération du débit de pointe aortique, comme index de contractilité myocardique, a diminué de façon significative et semblable dans les deux groupes, de manière dépendante de la dose, tandis que la vélocité maximale du DSA, une autre mesure de la contractilité myocardique, est demeurée stable. Le temps d'éjection ventriculaire de la fréquence cardiaque corrigée, comme mesure de précharge, est demeuré constant dans les deux groupes pour toutes les concentrations plasmatiques cibles.

Conclusion : Le propofol cause une baisse dose-dépendante du DSA et de la TAM ; mais avec $70 \%$ de $\mathrm{N}_{2} \mathrm{O}$, il produit des changements minimes de l'hémodynamique et des variables dérivées du Doppler avec une perfusion cible contrôlée à concentrations thérapeutiques de propofol.

From the Department of Anesthesia, Chiba Hokusoh Hospital, Nippon Medical School, ${ }^{*}$ Chiba; and the Department of Anesthesiology, Nippon Medical School Hospital, † Tokyo, Japan.

Present corresponding address: Dr. Toshiya Shiga, Department of Anesthesia, Nippon Medical School Chiba Hokusoh Hospital,

Kamagari 1715, Inba, Chiba 270-1694, Japan. Phone: 81-476-99-1843; Fax: 81-476-99-1931; E-mail: Shigat@aol.com

Presented in part at the 76th meeting of the International Anesthesia Research Society, San Diego, CA, USA, March 16-20, 2002.

Support came solely from institutional sources.

Accepted for publication January 28, 2003.

Revision accepted April 30, 2003. 


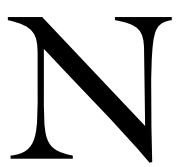

ITROUS oxide $\left(\mathrm{N}_{2} \mathrm{O}\right)$ is a frequently used adjunct to propofol anesthesia. Although $\mathrm{N}_{2} \mathrm{O}$ reduces the requirement of propofol for induction and maintenance, ${ }^{1}$ the effects of both drugs on overall hemodynamics remain controversial. The addition of $\mathrm{N}_{2} \mathrm{O}$ to propofol has been shown to increase the depression of global left ventricular (LV) systolic function in both normal and compromised canine myocardium in vivo. ${ }^{2}$ In healthy humans, the addition of $70 \% \mathrm{~N}_{2} \mathrm{O}$ to bolus propofol $2.5 \mathrm{mg} \cdot \mathrm{kg}^{-1}$ did not alter hemodynamic variables, including mean arterial pressure (MAP) and systemic vascular resistance. ${ }^{3}$ Few studies, however, have compared the effects of propofol at therapeutic concentrations titrated using target-controlled infusion technique (TCI) with and without $\mathrm{N}_{2} \mathrm{O}$ on global cardiac performance in normal human subjects.

The purpose of this study was, therefore, to test the hypothesis that the addition of $\mathrm{N}_{2} \mathrm{O}$ to therapeutic doses of propofol alters overall hemodynamics evaluated with the noninvasive esophageal Doppler monitor in normal human subjects.

\section{Methods}

After Institutional Review Board approval and written informed consent were obtained, 30 unpremedicated patients (ASA physical status I or II, aged 30-66 yr) scheduled for elective surgery were enrolled. Patients were randomly allocated to one of two groups: propofol with oxygen and air $\left(\mathrm{FIO}_{2}=0.3\right.$, air group $)$ or propofol with $70 \% \mathrm{~N}_{2} \mathrm{O}$ in oxygen $\left(\mathrm{N}_{2} \mathrm{O}\right.$ group). All patients received $7 \mathrm{~mL} \cdot \mathrm{kg}^{-1}$ of $6 \%$ hydroxyethyl starch as fluid replacement prior to anesthesia induction. A radial artery catheter was inserted to allow continuous blood pressure monitoring and blood sampling. After induction of anesthesia with fentanyl $2 \mu \mathrm{g} \cdot \mathrm{kg}^{-1}$ and midazolam $0.15 \mathrm{mg} \cdot \mathrm{kg}^{-1}$, tracheal intubation was facilitated with vecuronium, $0.15 \mathrm{mg} \cdot \mathrm{kg}^{-1}$, and the lungs were ventilated with a Modulus ${ }^{\circledR}$ CD anesthesia system (Ohmeda Inc., Madison, WI, USA). Normocapnia was maintained by end-tidal $\mathrm{CO}_{2}$ monitoring during the study. A 20-F esophageal Doppler probe was inserted orally, and connected to the esophageal Doppler monitor system (Hemosonic ${ }^{\mathrm{TM}} 100$, Arrow Japan, Tokyo, Japan). Time course of the experimental protocol is detailed in the Figure. The observer (T.S.) was blinded to whether air or $\mathrm{N}_{2} \mathrm{O}$ was administered. The properties of the variables have been described in a previous report. ${ }^{4}$ Briefly, peak aortic flow acceleration (Acc) is defined as the rate of change in aortic flow velocity at the onset of aortic flow. It occurs at the ejection phase of the systole and represents the maximum force exerted by the ventricle in early systole. ${ }^{5}$

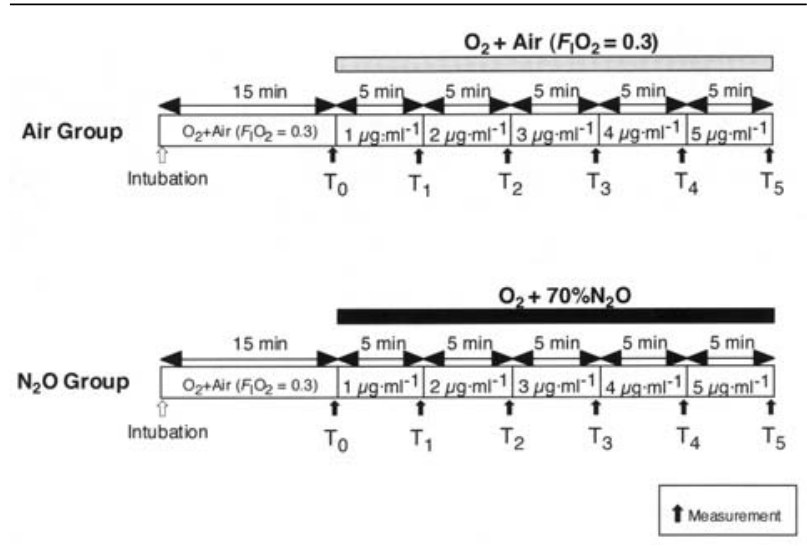

FIGURE Time course of the experimental protocol

After a 15-min stabilization period in both groups, a target-controlled infusion (TCI) technique was used to administer propofol at concentrations ranging from $0 \mu \mathrm{g} \cdot \mathrm{mL}^{-1}$ (baseline) to $5 \mu \mathrm{g} \cdot \mathrm{mL}^{-1}$ in 1- $\mu$ g steps. After a five-minute equilibration and confirmation via the software that each target plasma concentration was reached, Doppler variables were measured. $\mathrm{FIO}_{2}=$ inspired fraction of oxygen; $\mathrm{N}_{2} \mathrm{O}=$ nitrous oxide.

An infusion pump (Graseby 3500, SIMS Graseby Limited, Watford, UK) was operated on freely available computer software, ConGrase TCI version 1.5.1. ${ }^{\mathrm{A}}$ This software is designed according to the principle of a three-compartment pharmacokinetic model with Marsh's parameter sets. Using computer generated random numbers, 30 arterial blood samples (one from each patient) were withdrawn to confirm the accuracy between measured and predicted target plasma concentrations using high-performance liquid chromatography with fluorescence detection (BML, Inc., Tokyo, Japan). The percentage prediction error (PE) was calculated with the following formula: $\mathrm{PE}=[$ (measured propofol concentration - predicted propofol concentration)/ predicted propofol concentration] $\times 100$.

A priori power analysis was carried out on the basis of previous data $^{6}$ and our pilot study, suggesting that 15 patients per group would provide an $80 \%$ chance of detecting a $15 \%$ difference in Acc $(\alpha=0.05, \beta=0.20)$. Two-way ANOVA for repeated measures was done to detect significance between and within groups. One-way ANOVA for repeated measures followed by a StudentNewman-Keuls test for multiple comparison was used to

A) Program written by Osamu Nagata, MD, PhD; Department of Anesthesiology, Tokyo Women's Medical University, Tokyo, Japan. 
detect significance in intragroup differences. Unpaired Student's $t$ test was used to analyze intergroup differences at the same target plasma concentrations. Data are shown as mean $(\mathrm{SD})$ unless otherwise stated. A $P<0.05$ was considered statistically significant.

TABLE I Patient characteristics

\begin{tabular}{lll}
\hline & $\begin{array}{l}\text { Air group } \\
(n=15)\end{array}$ & $\begin{array}{l}N_{2} \text { O group } \\
(n=15)\end{array}$ \\
\hline Sex: $\mathrm{M} / \mathrm{F}$ & $7 / 8$ & $7 / 8$ \\
Age $(\mathrm{yr})[$ range] & $48.8 \pm 11.0[34-66]$ & $47.5 \pm 9.7[30-63]$ \\
Weight $(\mathrm{kg})$ & $60.7 \pm 14.1$ & $60.4 \pm 10.3$ \\
$\begin{array}{l}\text { Height }(\mathrm{cm}) \\
\begin{array}{l}\text { Probe distance from } \\
\text { the incisors }(\mathrm{cm})\end{array}\end{array}$ & $160.5 \pm 11.3$ & $163.8 \pm 9.6$ \\
\hline
\end{tabular}

Data are expressed as mean $\pm \mathrm{SD}$, unless otherwise indicated. Unpaired Student's t test and Chi square test were used to analyze differences. There was no significant difference between the two groups.

\section{Results}

Changes in hemodynamic and Doppler-derived variables in both groups at each target plasma concentration are shown in Table II. Acc decreased significantly in both groups in a dose-dependent manner. Stroke volume in aorta (SVa) exhibited different changes between the air and $\mathrm{N}_{2} \mathrm{O}$ groups. SVa remained unchanged in the air group, whereas it decreased significantly in the $\mathrm{N}_{2} \mathrm{O}$ group. Aortic blood flow (ABF) and MAP decreased significantly in a dose-dependent manner in both groups. ABF did not differ significantly between groups; in contrast, MAP in the $\mathrm{N}_{2} \mathrm{O}$ group showed a significantly greater decrease than that in the air group at T5. For the measured plasma propofol concentrations, the mean prediction error (MPE) was 12.4 $(30.3 \%$; $95 \%$ confidence interval $=1.1-23.7 \%)$, and the mean absolute prediction error $(\mathrm{M}|\mathrm{PE}|)$ was 25.4 $(20.2 \% ; 95 \%$ confidence interval $=17.9-33.0 \%)$.

TABLE II Hemodynamic variables following increasing propofol target plasma concentrations in air and $\mathrm{N}_{2} \mathrm{O}$ groups

\begin{tabular}{|c|c|c|c|c|c|c|}
\hline & \multirow[b]{2}{*}{ T0 (baseline) } & \multirow[b]{2}{*}{$T 1\left(1 \mu g \cdot m L^{-1}\right)$} & \multicolumn{4}{|c|}{ Target plasma concentrations } \\
\hline & & & $T 2\left(2 \mu g \cdot m L^{-1}\right)$ & T3 $\left(3 \mu g \cdot m L^{-1}\right)$ & $T 4\left(4 \mu g \cdot m L^{-1}\right)$ & $T 5\left(5 \mu g \cdot m L^{-1}\right)$ \\
\hline \multicolumn{7}{|c|}{$A B F\left(L \cdot \min ^{-1}\right)$} \\
\hline Air & $3.2 \pm 1.0$ & $3.1 \pm 1.0$ & $3.1 \pm 1.0$ & $3.0 \pm 1.0^{*}$ & $3.0 \pm 0.9^{*}$ & $3.0 \pm 0.9^{*}$ \\
\hline $\mathrm{N}_{2} \mathrm{O}$ & $3.1 \pm 1.1$ & $2.9 \pm 0.9^{*}$ & $2.8 \pm 0.8^{*}$ & $2.8 \pm 0.8^{*}$ & $2.8 \pm 0.9^{*}$ & $2.9 \pm 1.0^{*}$ \\
\hline \multicolumn{7}{|c|}{$H R\left(\right.$ beat $\left.\cdot \mathrm{min}^{-1}\right)$} \\
\hline Air & $65.8 \pm 5.5$ & $63.4 \pm 7.3^{*}$ & $62.2 \pm 8.0^{*}$ & $61.0 \pm 8.7^{*}$ & $60.5 \pm 8.6^{*}$ & $60.5 \pm 8.3^{*}$ \\
\hline $\mathrm{N}_{2} \mathrm{O}$ & $67.2 \pm 8.8$ & $65.3 \pm 8.3^{*}$ & $64.7 \pm 8.6^{*}$ & $65.0 \pm 8.6^{*}$ & $65.5 \pm 8.6^{*}$ & $65.6 \pm 8.19^{*}$ \\
\hline \multicolumn{7}{|c|}{$S V a(m L)$} \\
\hline Air & $48.9 \pm 14.6$ & $49.7 \pm 15.4$ & $50.2 \pm 16.4$ & $50.3 \pm 16.2$ & $49.7 \pm 15.4$ & $49.9 \pm 15.6$ \\
\hline \multicolumn{7}{|c|}{$\operatorname{Acc}\left(m \cdot \sec ^{-2}\right)$} \\
\hline Air & $9.4 \pm 2.1$ & $9.1 \pm 2.0$ & $8.8 \pm 2.0^{*}$ & $8.2 \pm 1.9^{*}$ & $7.9 \pm 1.7^{*}$ & $7.6 \pm 1.5^{*}$ \\
\hline $\mathrm{N}_{2} \mathrm{O}$ & $9.0 \pm 2.2$ & $7.9 \pm 1.6^{*}$ & $7.9 \pm 2.1^{*}$ & $7.6 \pm 1.8^{*}$ & $7.5 \pm 1.9^{*}$ & $7.2 \pm 1.7^{*}$ \\
\hline \multicolumn{7}{|c|}{$P V\left(\mathrm{~cm}^{\mathrm{sec}} \mathrm{C}^{-1}\right)$} \\
\hline Air & $66.5 \pm 15.1$ & $66.5 \pm 14.4$ & $66.5 \pm 14.5$ & $66.0 \pm 14.2$ & $66.2 \pm 14.1$ & $65.9 \pm 14.0$ \\
\hline $\mathrm{N}_{2} \mathrm{O}$ & $61.8 \pm 19.4$ & $60.0 \pm 17.5$ & $60.0 \pm 17.2$ & $60.7 \pm 16.7$ & $61.5 \pm 17.5$ & $61.6 \pm 17.8$ \\
\hline \multicolumn{7}{|c|}{ LVETi (msec) } \\
\hline Air & $389 \pm 15$ & $391 \pm 17$ & $391 \pm 17$ & $392 \pm 16$ & $392 \pm 15$ & $392 \pm 16$ \\
\hline $\mathrm{N}_{2} \mathrm{O}$ & $399 \pm 19$ & $401 \pm 13$ & $401 \pm 12$ & $400 \pm 13$ & $398 \pm 15$ & $401 \pm 17$ \\
\hline \multicolumn{7}{|c|}{ TSVRa $\left(\right.$ dyn $\left.\cdot \mathrm{sec} \cdot \mathrm{cm}^{-5}\right)$} \\
\hline Air & $2228 \pm 625$ & $2254 \pm 779$ & $2210 \pm 761$ & $2180 \pm 818$ & $2128 \pm 714$ & $2038 \pm 650^{*}$ \\
\hline $\mathrm{N}_{2} \mathrm{O}$ & $2455 \pm 870$ & $2347 \pm 771$ & $2249 \pm 664^{*}$ & $2151 \pm 675^{*}$ & $2093 \pm 657^{*}$ & $2017 \pm 636^{*}$ \\
\hline \multicolumn{7}{|c|}{$M A P(m m H g)$} \\
\hline Air & $83.2 \pm 8.7$ & $79.7 \pm 10.5^{*}$ & $77.1 \pm 9.3^{*}$ & $74.8 \pm 9.7^{*}$ & $72.2 \pm 8.5^{*}$ & $70.3 \pm 8.1 * \mathbb{I}$ \\
\hline $\mathrm{N}_{2} \mathrm{O}$ & $85.2 \pm 10.9$ & $78.2 \pm 8.9^{*}$ & $73.3 \pm 7.9^{*}$ & $70.2 \pm 7.1^{*}$ & $67.2 \pm 7.1^{*}$ & $65.0 \pm 5.8^{*}$ \\
\hline \multicolumn{7}{|c|}{ Aortic diameter $(\mathrm{mm})$} \\
\hline Air & $22.8 \pm 2.9$ & $22.7 \pm 2.9$ & $22.6 \pm 2.9$ & $22.5 \pm 3.0^{*}$ & $22.4 \pm 3.0$ & $22.5 \pm 3.0$ \\
\hline $\mathrm{N}_{2} \mathrm{O}$ & $22.6 \pm 2.3$ & $22.4 \pm 2.3^{*}$ & $22.1 \pm 2.5^{*}$ & $22.0 \pm 2.4^{*}$ & $21.8 \pm 2.5^{*}$ & $21.7 \pm 2.6^{*}$ \\
\hline
\end{tabular}

Data are expressed as mean $\pm \mathrm{SD} . \mathrm{ABF}=$ aortic blood flow; $\mathrm{HR}=$ heart rate; $\mathrm{SVa}=$ stroke volume in aorta; Acc $=$ peak aortic flow acceleration; PV = peak velocity of aortic flow; $\mathrm{LVETi}=\mathrm{HR}$-corrected left ventricular ejection time; TSVRa $=$ total systemic vascular resistance for aortic circuit; MAP = mean arterial pressure. SVa, TSVRa and LVETi are calculated with the following formula: SVa $=\mathrm{ABF} / \mathrm{HR}$, TSVRa $=(\mathrm{MAP} / \mathrm{ABF}) \times 80, \mathrm{LVETi}=\mathrm{LVET}+1.65 \times \mathrm{HR} .{ }^{*} P<0.05$ vs baseline; $₫ P=0.045: \mathrm{N}_{2} \mathrm{O}$ group vs air group. 


\section{Discussion}

Our investigation indicates that $70 \% \mathrm{~N}_{2} \mathrm{O}$ produces minimal hemodynamic effects under target-controlled propofol infusion at therapeutic concentrations. The majority of recent evidence indicates that propofol decreases myocardial contractility in vitro in animals; ${ }^{7}$ however, propofol is devoid of significant negative inotropic effect in normal human myocardium at therapeutic concentrations. ${ }^{8,9}$ Evidence suggests that only the free fraction of propofol is pharmacologically active because propofol bound to plasma proteins exceeds 95\%. ${ }^{8}$ Thus, in the present study, even at the $5 \mu \mathrm{g} \cdot \mathrm{mL}^{-1}$ concentration of propofol, myocardial depression was unlikely to occur.

In our studies, two indices of myocardial contractility are proposed. One is Acc and the other is peak velocity $(\mathrm{PV})$. Acc derived from continuous-wave Doppler technique correlates well with $\mathrm{LVdp} / \mathrm{dt}$ derived by an invasive technique, thereby serving as an index of myocardial contractility. PV was also reported to show a good correlation with LVdp/dt. ${ }^{5}$ In our study, Acc showed a significant dose-dependent decrease whereas PV remained unchanged by propofol. Although we did not clarify why this disparity occurred, one possible explanation is that PV may be less sensitive to changes of loading conditions than Acc. However, these are emerging indices, and their uses and limitations have yet to be extensively understood.

Left ventricular ejection time (LVETi) is reported to correlate closely with changes in preload. ${ }^{10}$ Theoretically, LVETi diminishes in correspondence with shortening of diastolic myocardial filling time, thereby indicating reduction in preload. DiCorte et al. ${ }^{10}$ have found that corrected flow time (nearly identical to LVETi) exhibits a better correlation with LV end-diastolic area, a widely accepted index of LV preload obtained from transesophageal echocardiography, than that exhibited by pulmonary artery diastolic pressure. Our results indicate that LVETi remained constant in both groups at any target plasma concentration. Although propofol has been reported to cause venodilation, our results suggest that preload remained almost constant because of adequate initial colloid fluid infusion and implies that preload was little affected by propofol either with or without $\mathrm{N}_{2} \mathrm{O}$ administration.

In conclusion, $70 \% \mathrm{~N}_{2} \mathrm{O}$ produces minimal changes in hemodynamic and Doppler-derived variables under target-controlled propofol infusion at therapeutic concentrations.

\section{References}

1 Stuart PC, Stott SM, Millar A, Kenny GN, Russell D. Cp50 of propofol with and without nitrous oxide $67 \%$.
Br J Anaesth 2000; 84: 638-9.

2 Diedericks J, Leone BJ, Foëx P, Sear JW, Ryder WA.

Nitrous oxide causes myocardial ischemia when added to propofol in the compromised canine myocardium. Anesth Analg 1993; 76: 1322-6.

3 Carlier S, Van Aken H, Vandermeersch E, Thorniley A, Byttebier $G$. Does nitrous oxide affect the hemodynamic effects of anesthesia induction with propofol? Anesth Analg 1989; 68: 728-33.

4 Boulnois JLG, Pechoux $T$. Non-invasive cardiac output monitoring by aortic blood flow measurement with the Dynemo 3000. J Clin Monit Comput 2000; 16: $127-40$.

5 Cucchini F, Di Mario C, Iavernaro A, Zeppellini R, Barilli A, Bolognesi R. Peak aortic blood acceleration: a possible indicator of initial left ventricular impairment in patients with coronary artery disease. Eur Heart J 1991; 12: 860-8.

6 Park WK, Lynch C III. Propofol and thiopental depression of myocardial contractility. A comparative study of mechanical and electrophysiologic effects in isolated guinea pig ventricular muscle. Anesth Analg 1992; 74: 395-405.

7 Gelissen HP, Epema AH, Henning RH, Krijnen HJ, Hennis PJ, den Hertog A. Inotropic effects of propofol, thiopental, midazolam, etomidate, and ketamine on isolated human atrial muscle. Anesthesiology 1996; 84: 397-403.

8 Sprung J, Ogletree-Hughes ML, McConnell BK, Zakhary $D R$, Smolsky SM, Moravec CS. The effects of propofol on the contractility of failing and nonfailing human heart muscles. Anesth Analg 2001; 93: 550-9.

9 Sabbah HN, Khaja F, Brymer JF, et al. Noninvasive evaluation of left ventricular performance based on peak aortic blood acceleration measured with a continuous-wave Doppler velocity meter. Circulation 1986; 74: 323-9.

10 DiCorte CJ, Latham P, Greilich PE, Cooley MV, Grayburn PA, Jessen ME. Esophageal Doppler monitor determinations of cardiac output and preload during cardiac operations. Ann Thorac Surg 2000; 69: 1782-6. 